\title{
HOW MANY NEW ASYLUMS DO WE NEED FOR THE IMBECILES? NÁPRSTEK'S NURTURING OF PHILANTHROPY
}

\author{
Milena Secká ${ }^{+}$
}

\begin{abstract}
A part of the collections of the Náprstek Museum also includes exhibits documenting the life and activity of Vojta Náprstek. Among them belong thirty paintings of educational and social institutes of the Anglo-American world. They were painted by Alois Studnička, and Vojta Náprstek displayed them in 1865 at an exhibition at Žofín in Prague. The exhibition of more than a hundred paintings was accompanied by lectures not only concerning these institutions, but also concerning patrons who founded and supported these institutions. At the same time, he encouraged the listeners to follow his own example of promoting patronage.
\end{abstract}

KEYWORDS: Vojta Náprstek - patrons - educational institutes - social institutes

According to the well-known Prague patriot ${ }^{1}$ and patron Vojta Náprstek, ${ }^{2}$ the answer is a resounding 'none'. If a society is functioning well, it can finance the necessary institutes by itself.

On 27 March 1865, Vojta Náprstek opened his exhibition of paintings of educational and social institutes in the Anglo-American world [Pls. 1-3], which was complemented by lectures. More than a hundred exhibits presented the buildings of institutions, which were designed indiscriminately for all in need. He drew attention to the phenomenon of patronage which the exhibition was supposed to encourage. Although the exhibition only lasted until 2 April, it was supplemented by three lectures by Vojta Náprstek, of which the public already knew from his previous public lectures related to women's education in particular and the need to establish an industrial museum. The lectures

1 The manuscript was edited and some of the footnotes were added under the supervision of Martin Šámal. This work has been made possible by the financial support of the Ministry of Culture within the framework of institutional and conceptual development to the National Museum as a research organization (DKRVO 2019-2023 / 15.I.b. 00023272).

2 Vojta Náprstek (1826-1894) was a Czech patriot, philanthropist and patron, founder of the Czech Industrial Museum (present-day Náprstek Museum), and local politician. During his studies at the faculty of Law at the University of Vienna, he participated in the Revolution of 1848 and subsequently left for America, where he spent ten years. Owing to his American stay, he became, after his return well aware of the underdevelopment of Czech society and strived to edify it by all means possible. Above all, he considered education to be the solution. He founded a library and later a museum which was supposed to introduce the general public with the newest inventions and novelties. He also became a pioneer and supporter of the emancipation and education of women. In 1865 he gave part of his renowned library to the newly established Ladies' American Club for the purposes of education and lecturing. For more on Náprstek see Kodym 1955; Secká 2011; Šolle 1994. 
were published in the daily press. $^{3}$ In them the author provided very detailed statistics on the individual institutions which he obtained from the foreign press. For some institutions, he also stated the number of places, prospective beds, equipment, the opportunities of clients, the daily routine, or operating costs. In addition, Náprstek introduced listeners to distinguished patrons (Vassar, ${ }^{4}$ Smithson, ${ }^{5}$ Cooper $^{6}$ etc.). The exhibition of paintings was complemented by portraits of several world-famous patrons which came from Náprstek's library.

Náprstek was already interested in the social issues of society during his American emigration (1848-1857). ${ }^{7}$ He wanted to learn about and get to know the modern and progressive views which he could later apply in his homeland. In 1862 he participated in an expedition to the World's Fair in London with a group of patriots. On that occasion, he visited several institutes and recorded the statistical data in his diary. His interest continued from 1870 and he tried to use the information he gained as a Prague councillor.

The author of the exhibited paintings was Alois Studnička, ${ }^{8}$ one of Náprstek's longtime friends. The set of images consists of watercolor paintings on wrapping paper with the labels written in ink in Czech and in English. The images have a different format, most often around $130 \times 90 \mathrm{~cm}$, but formats of $230 \times 115 \mathrm{~cm}$ are no exception. All capture individual buildings, sometimes intimated by the surroundings. The paintings are finely coloured, some only in shades of grey. The characters are captured minimally in the depictions. The buildings depicted are schools, colleges, hospitals, libraries, and other social institutions which draw attention to their architecture among other things. In many cases the buildings are very opulent and reminiscent of aristocratic residences. The institutes represented are from England, Scotland, the USA, and India, and the author also wanted to show that even the socially weak and handicapped can live in a dignified environment. All of these were built only thanks to patrons whose gifts and bequests made this possible. In his lectures Náprstek emphasized that anyone could be a patron, even if they gave only a minor contribution. His statement 'We Czechs

3 A notice about Náprstek's lecture was published e.g. by Národní škola, týdenník vychovatelský pro národní učitelstvo v Čechách, na Moravě, v Slezsku a na Slovensku (National School, a weekly pedagogical magazine for the national teachers in Bohemia, Moravia, Silesia and Slovakia), 1865, no. 12, p. 95 from 23.3.1865. The magazine published a short report about the lectures held together with a promise that more elaborate accounts of the lectures' content were going to be published in the upcoming issues. This was truly fulfilled in no. 15, p. 117 from 13.4.1865; no. 16, p. 126 from 20.4.1865; no. 17, pp. 134-135 from 27.4.1865. A more elaborate report and transcript were published by the Národní listy (National Newspaper), 1865, vol. 5, no. 85 from 27.3.1865; no. 86 from 28.3.1865; no. 93 from 4.4.1865. A short notice about the lectures appeared also in German newspaper Bohemia, 1865, no. 72, p. 873874 from 25.3.1865. It is interesting to point out that the lectures were noticed also by compatriot press, namely Pozor. Nové občanské noviny (Attention. New Citizen's Newspaper) published in St. Louis by Náprstek's friend Karel Alis. He published an abridged transcript of the lectures under the title 'Snahy vlastenců. Přednášky P. Náprstkovy o ústavech dobročinných v Praze na Žofínském ostrově (Endeavours of the patriots. Lectures of Mr. Náprstek about charitable institutions at Prague in the Žofín Island)' in no. 43 from 3.5.1865; no. 44 from 6.5.1865; no. 45 from 10.5.1865.

Mathew Vassar (1792-1868), an American patron.

5 James Smithson (1765-1829), an American patron.

6 Peter Cooper (1791-1883), an American patron.

7 Šámal 2017; Památce Vojty Náprstka ve sté výročí jeho narozenin, 1926, p. 7.

8 Alois Studnička (1842-1927), a professor at the Czech Polytechnic. 
spent ten million last year only on cigarettes! ${ }^{\prime 9}$ was a strong argument for those who objected that our society was too poor to support patronage. Náprstek also mentioned the names of the institutions which were to support and gave assurance that the financial resources would be used appropriately. These institutes included the National Museum, Matice česká, the Svatobor Association, and the Academic Readers Society. He also recommended supporting any schools, hospitals (specializing in individual maladies), artistic discussions, industrial unions, the National Theatre and regional theatres, and asylums for the physically and mentally disabled. He also called attention to women's institutes (Pedagogium, Industrial School for Girls, the Society of Saint Ludmila, orphanages, foundlings, cooking schools, heating rooms, and public canteens and laundries). It is important that Náprstek mentioned that these institutions: 'had not yet been established in our country.' These would include an industrial museum, public libraries, an association for helping released prisoners, an institute for delinquent youth, schools for workers and their children, or a public picture gallery. According to Náprstek, it was possible for almost everyone to make a contribution and there was no need to solicit the state for contributions or support. He himself set an example by supporting several associations and institutes, and he even provided an education to five orphans. ${ }^{10}$

In the Náprstek Museum the paintings mentioned have been preserved only in a limited number. After the exhibition ended, Náprstek placed paintings on the wall of the courtyard balcony of his house U Halánků, as evidenced by photography of that period [Fig. 1]. The weather was certainly not optimal for the images, and thus it was reflected in their condition. The entire preserved set is part of the Náprstek's inventory sub-collection (Inv. Nos. N 02.171-N 02.206). In the collection of historical photographs, the buildings mentioned were photographed by the well-known Prague photographer Eckert [Fig. 2]. ${ }^{11}$ The inventory is apparently complete even with detailed descriptions on the reverse side, and thanks to these photographs we can reconstruct the original set.

Through his exhibition and lectures, Vojta Náprstek highlighted the problem of the necessity of institutes for developing societies. The development of industry and education but also science and technology brought along new problems and requirements with it. We do not know whether Náprstek's exhibition had any repercussions in the form of concrete bequests, but helping Czech institutions became one of the manifestations of Czech patriotism.

9 Národní listy (National Newspaper), 1865, no. 86 from 28.3.1865. Variant of Náprstek's quote: '...yes, we are so rich that in 1863 just in Bohemia 10 million crowns were spent for smoking (tobacco)'. Compare Pozor. Nové občanské noviny (Attention. New Citizen's Newspaper), 1865, no. 45, p. 2 from 10.5.1865.

10 For Náprstek's membership in charitable associations see Secká 2011, p. 104-110, 275-276; Secká and Šámal 2015, p. 197-198. Concerning the orphans taken care of by Náprstek and his wife see Secká 2011, p. 244; Secká 2016, p. 94.

11 Jindřich Eckert (1833-1905), a renowned Prague photographer. Two of his photographs are known of the courtyard balcony of the house U Halánků with the exhibited paintings; Náprstek Museum, Collection of the historical photographs, Inv. Nos. 2.0823, 2.0826. 


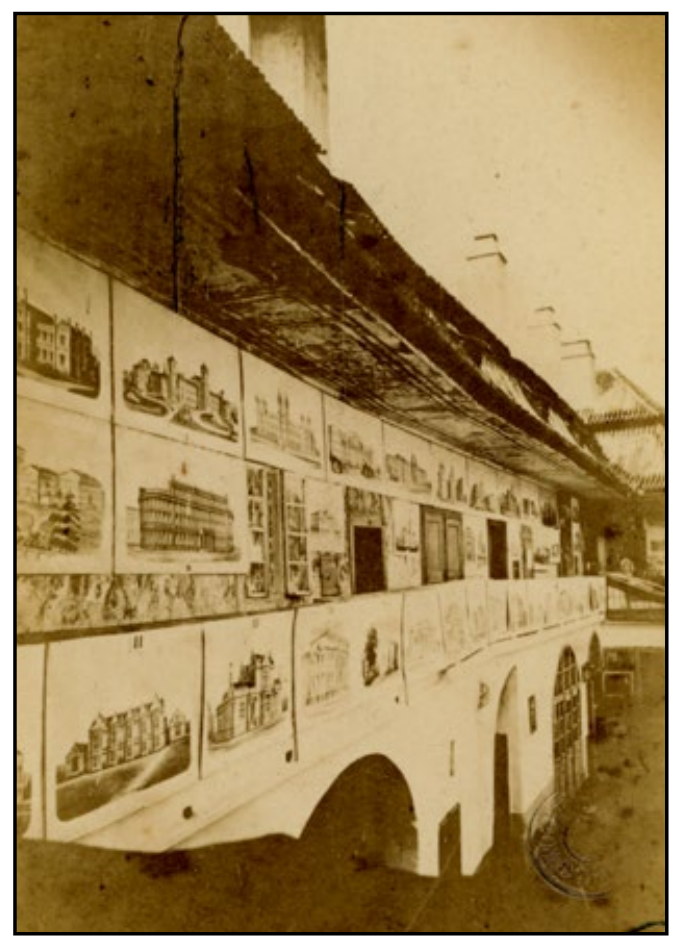

Fig. 2. Three photographs from the set depicting the charitable institutions, Archive of the Náprstek Museum, Vojta Náprstek Personal Papers, Box $73 / 10$, nos. $45,48,74$.
Fig. 1. A view of the courtyard balcony of the house

U Halánků with the exhibited paintings of charitable institutions, Inv. No. 109.19 (Photo: Jindřich Eckert).

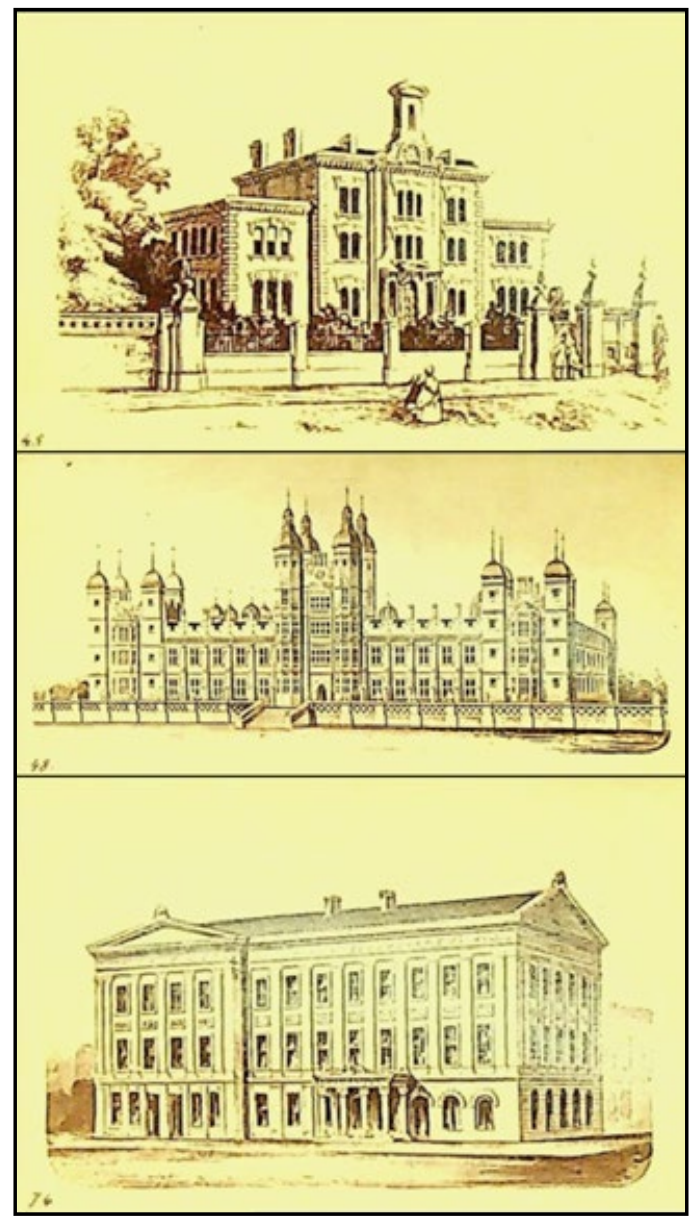




\section{Literature:}

Kodym, S. (1955). Dům u Halánků: vzpominky na Vojtu Náprstka. Praha.

Secká, M. (2011). Vojta Náprstek: Vlastenec, sběratel, mecenáš. Praha.

Secká M., Šámal M. (2015). Sociální cítění manželů Náprstkových. In: Útisk - charita - vyloučení. Sociální 19. století. Sbornik př́spěvkủ z 34. ročniku mezioborového sympozia k problemastice 19. století. Plzeň 27.2.-1.3.2014. Praha, pp. 190-201.

Šámal, M. (2017). Jsem svobodný...: edice rodinné korespondence Vojty Náprstka 1848-1858. Praha.

Šolle, Z. (1994). Vojta Náprstek a jeho doba. Praha.

Náprstkovo poselství před odjezdem do Ameriky. (1926). In: Památce Vojty Náprstka ve sté výročí jeho narozenin. Praha.

\section{Archival sources:}

Archive of the Náprstek Museum, Vojta Nápsrtek Personal Papers:

Box $2 / 1 \quad$ Extract book

Box 68/63 Náprstek's contributions about charitable institutions

Box 72/34 List of charitable institutions. V. Náprstek's lectures in Prague from 26 and 27 March 1865 about modern philanthropy

Box 72/53 Poster of V. Náprstek's lecture about charitable institutions.

Box $73 / 10 \quad$ Photo of charitable institutions $(5 \times 7 \mathrm{~cm})-39$ pieces

Box 102/16 List of charitable institutions. 


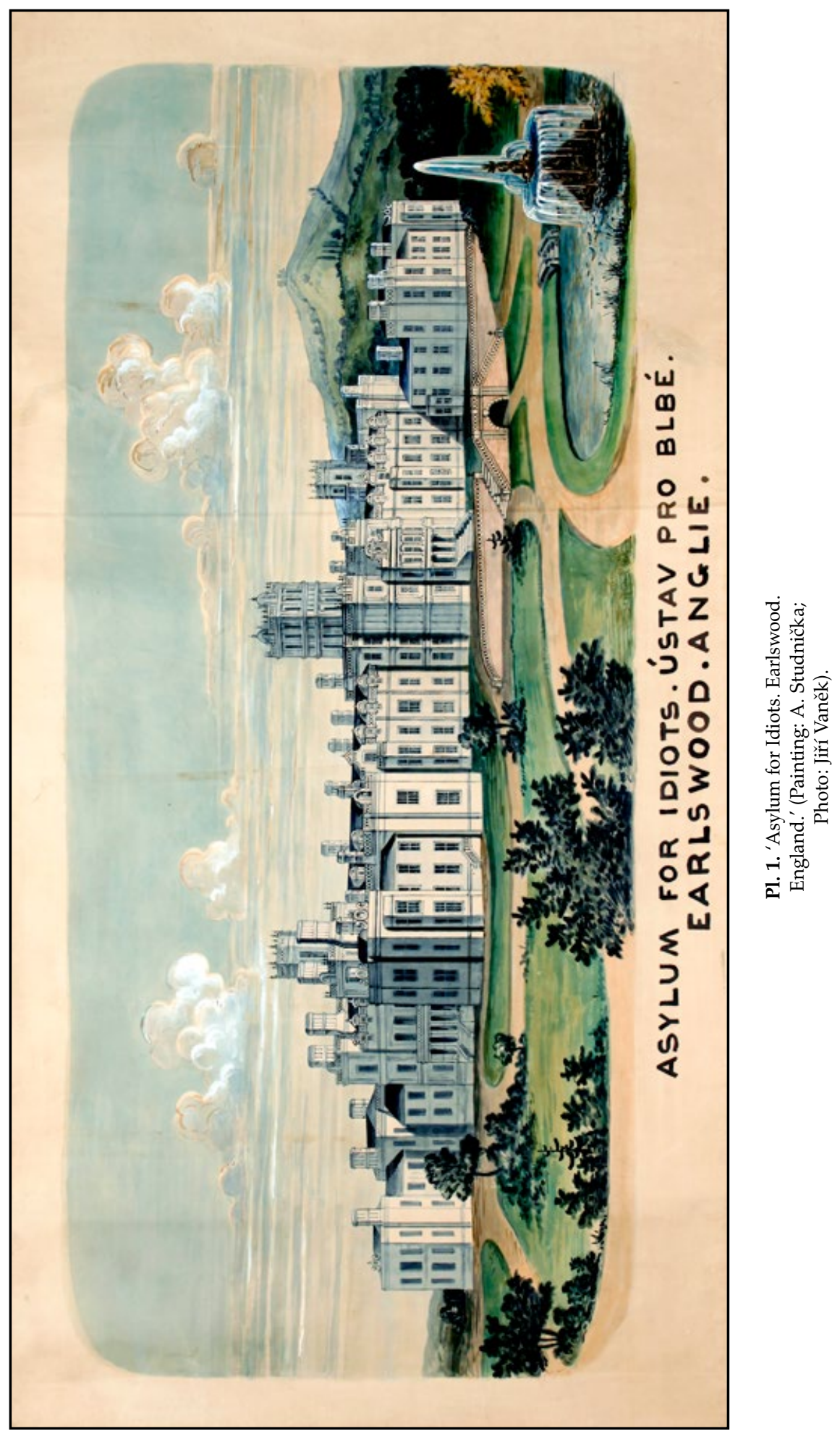




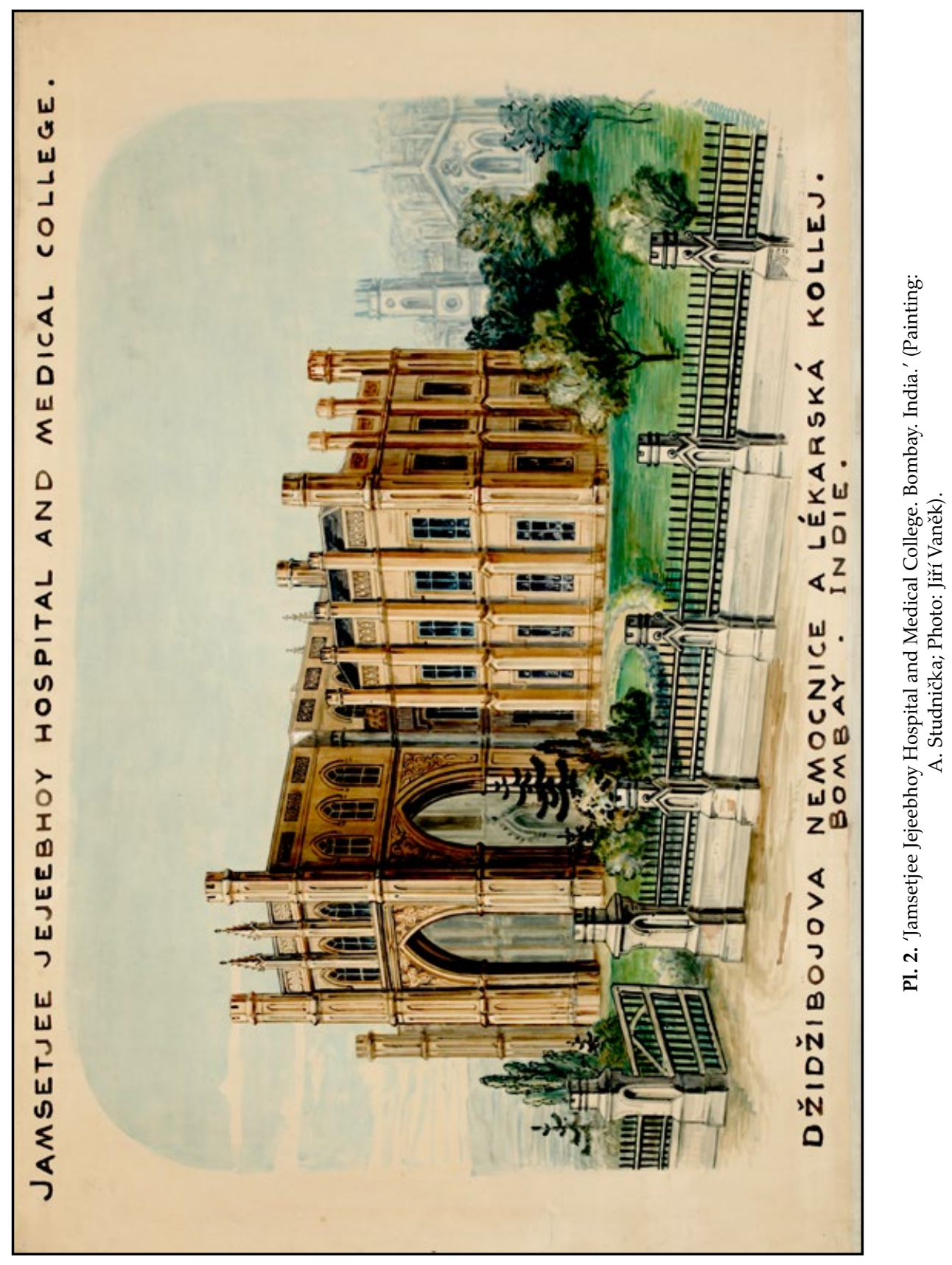

$\underset{\Xi}{\sharp}$ 


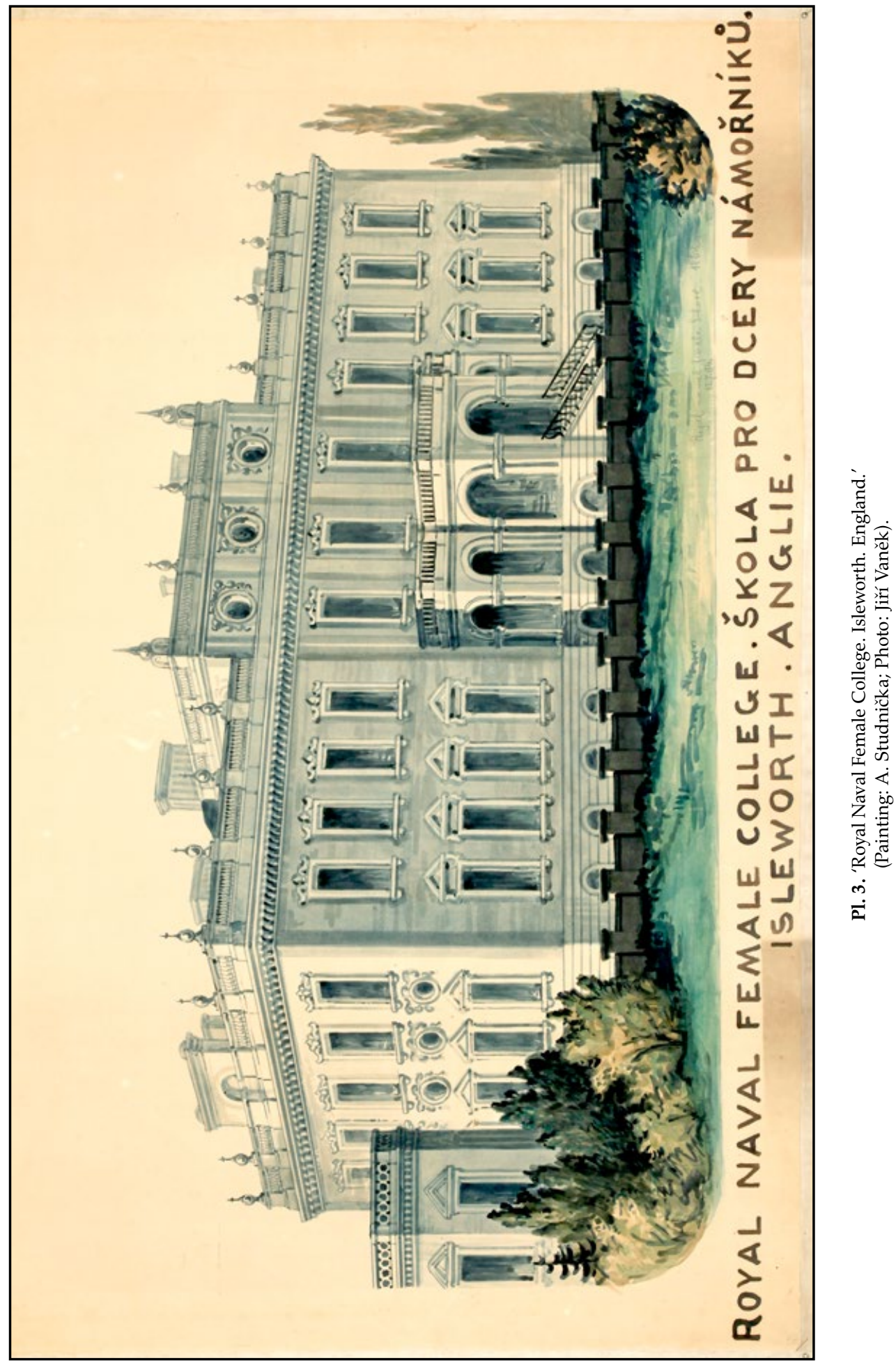

